Original Contribution

\title{
DETERMINANTS OF POVERTY AMONG LOCAL RICE PROCESSORS IN KWARA STATE, NIGERIA
}

\author{
M. F. Salami* , R. O. Babatunde, O. E. Ayinde, E. I. Adeoti \\ Department of Agricultural Economics and Farm Management, Faculty of Agriculture, \\ University of Ilorin, Ilorin, Kwara State, Nigeria
}

\begin{abstract}
This study accessed the extent and determinants of poverty among local rice processors in Kwara state. Primary data were obtained through questionnaire and interview schedule. Data were subjected to descriptive statistics, Foster-Greer-Thorbecke (FGT) class of decomposable poverty and logistics regression analysis. The result of the descriptive statistics show that majority (97.5\%) of the rice processors are female and substantial number $(83.33 \%)$ of the rice processors do not have other source of income apart from rice processing. The result of the FGT class of decomposable poverty showed that poverty is more intense or severe in households with small household size. The results of the logit regression showed that gender (female), educational status, income and household size were significant poverty determinants in the study area. Higher educational status, larger income and larger household size are poverty reducing while increase in gender (female) is poverty enhancing. It is therefore recommended that government and other stakeholders should invest more in the education of the rice processors. The rice processors should as well be encouraged to engage secondary occupation so as to earn more income. Also, men should be encouraged to be involved in rice processing in the study area.
\end{abstract}

Key words: Processing, Logit regression, FGT, income, secondary occupation, Edu LGA, decomposable Poverty, Snowball sampling technique

\section{INTRODUCTION}

Poverty is more easily recognized than defined (1). Therefore, a universally acceptable definition of the term has remained elusive (2). However, poverty can be regarded as the inability to adequately meet the basic human necessities, such as food, shelter, clothing and Medicare. It is also a state of deprivation of human needs to which a person, household, community or nation can be subjected to. (3)

Poverty is one of the greatest challenges facing the world today. Globally, extreme poverty continues to be a rural phenomenon despite increasing urbanization. Out of the world's 1.2 billion extremely poor people, 75 percent live in rural areas and they largely depend on agricultural practices such as: forestry, fisheries and related activities for survival (4). Poverty is strongly influenced by education and location but in Nigeria, poverty is seen as a rural problem where majority of the inhabitants

\footnotetext{
*Correspondence to: Salami M. F., Department of agricultural Economics and farm Management, Faculty of Agriculture, P.M.B. 1515, University of Ilorin, Ilorin, Kwara State, Nigeria, markmercy12@gmail.com, +2347030473809
}

engage in agricultural production as a means of livelihood (5). In fact rural poverty is widely regarded as the main constituent of poverty (5$6)$.

Agricultural growth is especially effective in reducing poverty. Cross-country econometric estimates show that overall GDP growth originating in agriculture is, on average, at least twice as effective in benefiting the poorest half of a country's population as growth generated in nonagricultural sectors. Indeed, many countries that had relatively high agricultural growth rates saw substantial reductions in poverty: China's rapid growth in agriculture was initially responsible for the rapid decline in rural poverty from 53 percent in 1981 to 8 percent in 2001 (7).

Agriculture was also the key to India's slower but still substantial long-term decline of poverty. Most recently, Ghana is Africa's breaking story of a 24 percentage point reduction in rural poverty over 15 years, in part because of recent strong agricultural performance. The agricultural sector of Nigerian economy contributes significantly to 
rural employment, food security, and provision of industrial and raw materials (8).

The small-scale agriculture have always occupied a very important part in agricultural production in Nigeria and the country has a comparative advantage in the production of cocoa, rice, cassava, sorghum, peanut, palm oil, millet, corn, yam, rubber, cattle, fish, timber and many other crops. In developing countries, rural agriculture/communities are critically important for food supply, especially rice which is a staple food (9).

Rice is an annual crop and the most important staple food crop in the tropical countries. Commercially, the crop is the most important cereal after wheat. It is widely consumed and there is hardly any country in the world where it is not utilized in one form or the other. In Nigeria, rice is one of the few food items whose consumption has no cultural, religious, ethnic or geographical boundary. It is available in five-star hotels in the big cities and towns, as well as in the "most local" of the eating places in the remotest villages throughout the country. It is highly priced and widely accepted for festivity. (10)

Since the mid-1980s, rice consumption has increased at an average annual rate of 11 per cent of which only 3 per cent can be explained by population growth. The remainder represents a shift in diet towards rice at the expense of the coarse grains (millet and sorghum) and wheat. Nigeria's demand for rice is roughly four million tonnes annually. Rice imports account for close to a third of Nigeria's total rice supplies (11).

Harvested rice is in its basic form which is known as "rough rice" and it is still covered by a non-edible hull or husk. For this reason, rice has to be processed to the edible white rice which is handled by the rice processors. Rice processors are certain group of farmers which may not even be rice farmers that is they may not plant rice but they processed it from the non-edible rough rice to the edible white rice. The rice processors that are not rice farmers bought the rough rice from the rice farmers at lower price rate, processed it to edible rice and sell it to the consumers at higher price rate.

Most Nigerians prefers to consume imported rice as compared to local rice The reason is that, the local rice were not polished, they may contain foreign materials like stones, they are not parboiled etc. because most Nigerian rice processors lack adequate technology of rice processing to meet international standard. Therefore, people prefer to buy the imported rice which is clean and polished for time and health safety.

In spite of the effort to put in place by the millennium development goal programme, poverty is still ravaging our society. To achieve poverty reduction, it becomes necessary to empirically profile poverty prevalence and factors influencing poverty among farm households. This gap in knowledge is what this research hope to fill. The specific objectives are to: describe the Socio-economic characteristics of the local rice processors in the study area; analyze the extent of poverty among the local rice processors in the study area and identify the determinants of poverty among the local rice processors in the study area.

\section{METHODOLOGY}

\section{The study area}

The study was conducted in Kwara State, Nigeria. The state is located in the North Central part of the country and is made up of sixteen (16) Local Government Areas (LGAs). The state lies between latitude $7015^{\prime} \mathrm{E}$ and $6018^{\prime} \mathrm{N}$ of the equator and has a population of about 2.37 million people (National Population Commission, 2006). It shares local boundaries with Oyo, Osun, Ondo, Kogi, Ekiti, and Niger states

\section{Sampling technique:}

Edu local government area of Kwara state was purposively selected because it is predominantly known for rice production. 5 villages namely: Lafiagi, Tsaragi, Gbugbu, Shonga and Ogudu were randomly selected within the local government area. The respondents (Local Rice Processors) were reached through the snowball sampling technique. A total of 120 rice processors were interviewed for the purpose of this study.

\section{Data collection:}

Primary data was use for this study and the data were harnessed through the use of questionnaire in conjunction with interview schedule. This is because most of these local rice processors can neither read nor write.

\footnotetext{
Data analysis

Descriptive statistics

Descriptive statistics which include frequency and percentage is used to analyze the socio economic characteristics of the rice processors. The FGT poverty index was used to analyze Extent of poverty among the rice processors: It is given by:
} 
$P_{\alpha}(y, z)=\frac{1}{2} \sum_{i=1}^{q}\left(\frac{z-y_{i}}{z}\right)$

Where: $\mathrm{n}=$ total number of households in population

$\mathrm{q}=$ the number of poor households

$\mathrm{Z}=$ the poverty line for the household

$\mathrm{y}_{\mathrm{i}}=$ household income

$\alpha=$ poverty aversion parameter and takes on value $0,1,2$

$\left(\frac{Z-y_{i}}{Z}\right)_{=\text {proportion shortfall in income }}$ below the poverty line

$P_{1}=\frac{1}{2} \sum_{i=1}^{q}\left(\frac{z-y_{i}}{z}\right)$

This is called Poverty depth or Poverty gap index, which measures the extent to which individuals fall below the poverty line as a proportion of the poverty line.

$P_{2}=\frac{1}{n} \sum_{i=1}^{q}\left(\frac{z-y_{i}}{z}\right)^{2}$

This is called Poverty severity index measures the squares of the poverty gaps relative to the poverty line.

Construction of Poverty Line: This was done to categorize the respondents into poor and non-poor groups using the two-third mean percapita income as the benchmark, which was adopted from the studies carried out by Households whose mean per-capita income falls below the poverty line are regarded as being poor while those with their per-capita income above the benchmark are non-poor.

Total Per - capita Income (TPCI) = Summation of PC

Mean TPCI

$=$ TPCI $/$ T otal Number of Households

$=\mathrm{MTPCI}$

Per - capita income (PCI) = Income $/$ Household Size

Poverty Line $(\mathrm{PL})=2 / 3 \times \mathrm{MTPCI}$

Logit Regression Model.

This was used to analyze the determinants of poverty among the rice processors. The explicit form of the model is given as

$\mathrm{Y}=f\left(\mathrm{X}_{1}, \mathrm{X}_{2}, \mathrm{X}_{3} \ldots \ldots \mathrm{X}_{\mathrm{n}}+\mathrm{ei}\right)$

Where,

$\mathrm{Y}=1$ if household is poor and 0 if household is not poor
$\mathrm{X} 1=$ Age of the rice processor

$\mathrm{X} 2=$ Gender of the rice processor

$\mathrm{X} 3=$ Education status of the rice processor

$\mathrm{X} 4=$ Household size

$\mathrm{X} 5=$ Dependency ratio (Proportion of children and aged in the household)

X6 $=$ Presence of secondary occupation

$\mathrm{X} 7=$ Access to Credit

$\mathrm{X} 8=$ Income of the rice processor

$\mathrm{X} 9=$ Number of rice processing cycle

\section{RESULTS AND DISCUSSION}

Table 1 shows that majority $(97.5 \%)$ of the rice processors are female. Most of them $(51.67 \%)$ are within the age group of $40-50$ years. Majority $(81.67 \%)$ of the rice processors are married. $55.83 \%$ of them had no formal education and $50 \%$ of them are from households that comprises of about 6-10 member. Most of the rice processors (88.33\%) do rice processing as their primary occupation. $80 \%$ of the rice processors does about 4 processing cycle in a month. $71.67 \%$ of them earn about $\$ 10,000$ per processing cycle. $55.83 \%$ of them earn $\$ 30,000$ per month from rice processing. $75.83 \%$ of the rice processor make use of family labour and $55 \%$ of them spend about $\$ 20,000$ per month.

\section{Construction of Poverty line to determine the Poverty Status of Respondents (Household's head)}

The household total expenditure on food and non-food items was used in classification of the households into poor and non-poor. This was done in two ways:

i. The first was the moderate poverty line which is equivalent to $2 / 3$ of the mean per capita household expenditure.

ii. The core or very poor poverty line which is equivalent to $1 / 3$ of the mean per capita household expenditure was also drawn. The households were classified into one of the mutual exclusive groups separated by poverty line either as:

a. Core Poor

b. Moderate poor

c. Non-poor

Mean Per Capita Household Expenses $($ MPCHHE $)=$ Total households expenses/ number of respondents

Where,

Total expenditure $=\mathrm{N} 2,354,450$

Number of respondents $=120$

MPCHHE $=2,354,450 / 120=$ N19, 620

Moderate poverty line (i.e. $2 / 3 \mathrm{MPCHHE}$ ) $=$ $2 / 3 \times \mathrm{N} 19,620=\mathrm{N} 13,080$

Core poverty line (i.e. $1 / 3 \mathrm{MPCHHE})=1 / 3 \mathrm{x}$ $\mathrm{N} 19,620=\mathrm{N} 6,540$ 
Table 1. Socio-economics characteristics of Respondents $(n=120)$

\begin{tabular}{|c|c|c|}
\hline Variable & Frequency & Percentage \\
\hline \multicolumn{3}{|c|}{ Gender of Household Head } \\
\hline Male & 91 & 75.83 \\
\hline Female & 29 & 24.17 \\
\hline \multicolumn{3}{|l|}{ Gender of rice processor } \\
\hline Male & 3 & 2.5 \\
\hline Female & 117 & 97.5 \\
\hline \multicolumn{3}{|l|}{ Age of rice processor } \\
\hline$<40$ years & 25 & 20.83 \\
\hline 40-50years & 62 & 51.67 \\
\hline 51-60years & 18 & 15 \\
\hline$>60$ years & 15 & 12.5 \\
\hline \multicolumn{3}{|c|}{ Marital status of rice processor } \\
\hline Single & 14 & 11.67 \\
\hline Married & 98 & 81.67 \\
\hline Divorced & 0 & 0 \\
\hline Widow & 8 & 6.67 \\
\hline \multicolumn{3}{|c|}{$\begin{array}{l}\text { Educational status of rice } \\
\text { processor }\end{array}$} \\
\hline No formal education & 67 & 55.83 \\
\hline Primary education & 27 & 22.5 \\
\hline Secondary education & 13 & 24.17 \\
\hline Tertiary education & 9 & 7.5 \\
\hline Others & 4 & 3.33 \\
\hline \multicolumn{3}{|l|}{ Household size } \\
\hline $0-5$ & 19 & 15.83 \\
\hline $6-10$ & 60 & 50 \\
\hline $11-15$ & 32 & 26.67 \\
\hline$>15$ & 9 & 7.5 \\
\hline \multicolumn{3}{|l|}{ Primary occupation } \\
\hline Rice processing & 106 & 88.33 \\
\hline Civil servant & 9 & 7.5 \\
\hline Trading & 5 & 4.17 \\
\hline \multicolumn{3}{|c|}{ Income Per cycle of rice processing } \\
\hline $0-\# 10,000$ & 86 & 71.67 \\
\hline$\# 11,000-\# 20,000$ & 24 & 20 \\
\hline$>\# 21000$ & 10 & 8.33 \\
\hline \multicolumn{3}{|c|}{ Number of cycle per month } \\
\hline $0-4$ & 96 & 80 \\
\hline Above 4 & 24 & 20 \\
\hline \multicolumn{3}{|c|}{$\begin{array}{l}\text { Monthly income from rice } \\
\text { processing }\end{array}$} \\
\hline $0-\# 30,000$ & 67 & 55.83 \\
\hline$\# 31,000-\# 60,000$ & 38 & 31.67 \\
\hline$>\# 60,000$ & 15 & 12.5 \\
\hline \multicolumn{3}{|l|}{ Monthly expenditure } \\
\hline$<\# 10,000$ & 10 & 8.33 \\
\hline$\# 10,000-\# 20,000$ & 66 & 55 \\
\hline$\# 21,000-\# 30,000$ & 35 & 29.17 \\
\hline$>\# 30,000$ & 9 & 7.5 \\
\hline \multicolumn{3}{|l|}{ Sources of labour used } \\
\hline Family labour & 91 & 75.83 \\
\hline Hired labour & 29 & 24.17 \\
\hline Communal labour & 0 & 0 \\
\hline Others & 0 & 0 \\
\hline \multicolumn{3}{|l|}{ Sources of fund } \\
\hline Cooperative & 19 & 15.83 \\
\hline Money lenders & 14 & 11.67 \\
\hline Personal funds & 82 & 68.33 \\
\hline Other sources & 5 & 4.17 \\
\hline \multicolumn{3}{|c|}{ Membership of cooperative society } \\
\hline Yes & 24 & 20 \\
\hline No & 96 & 80 \\
\hline \multicolumn{3}{|l|}{ Access to loan } \\
\hline Yes & 19 & 15.83 \\
\hline No & 101 & 84.17 \\
\hline
\end{tabular}

Field survey, 2016 
SALAMI M. F., et al.

The analysis of the data shows in Table 2 reveals that, of the total rice processor, $(42 \%)$ are non-poor while $(58 \%)$ are poor. Out of those rice processors that are poor, about $19 \%$ are extremely poor while $39 \%$ are moderately poor, that is, they fall below the poverty line.

Table 2. Poverty Incidence of Rice Processors

\begin{tabular}{|l|l|l|}
\hline Poverty status & Frequency & Poverty incidence \% \\
\hline Core Poor & 16 & 19 \\
\hline Moderate Poor & 54 & 39 \\
\hline Non-Poor & 50 & 42 \\
\hline
\end{tabular}

Field Survey, 2016

Extent of poverty among the Rice processors: Decomposition of poverty

$\mathrm{P}_{0}$ shows the proportion of the population that falls below the poverty line, $\mathrm{P}_{1}$ is the average depth of poverty for the poor (is the amount needed to bring the corresponding rice processors out of poverty) and the $\mathrm{P}_{2}$ shows the severity of poverty in each case.

The result shows the rice processors of $58.33 \%$ are below poverty line. To bring these people out of poverty, 0.4034 are needed for the affected poor people. $\mathrm{P}_{2}$ shows the severity of poverty in above and for all $\alpha>0$, the measure is strictly decreasing in the living standard of the poor (the lower your standard of living, the poorer you are deemed to be). Furthermore, for $\alpha>1$ it also has the property that the increase in measured poverty due to a fall in one's standard of living will be deemed greater the poorer one is. The measure is then said to be "strictly convex" in incomes (and "weakly convex" for $\alpha<1$ i.e. $0.0014<1$ ). (Table 3)

Table 3. Poverty Indices

\begin{tabular}{|l|l|l|l|l|}
\hline Characteristics & Frequency & $\mathrm{P}_{0}$ & $\mathrm{P}_{1}$ & $\mathrm{P}_{2}$ \\
\hline Respondents & 120 & 0.5833 & 0.4034 & 0.0014 \\
\hline
\end{tabular}

Data analysis, 2016

\section{Determinants of Poverty among the Rice Processors}

Table 4 reports the log likehood estimates of logit regression model. The coefficient of household size of -0.0832 has a negative significant influence on poverty at $10 \%$. The implication of this is that a unit increase in the household size will decrease poverty level by $8 \%$. This is in line with the findings of (12) the reason for this is that most of the rice processors in the study area use family labour as their source of labour and increase in household size tend to decrease their poverty level in the sense that money use in hired labour will be reduced when the household size is increased. The coefficient of educational status of -1.0900 has a significant influence on poverty at $5 \%$ meaning that a unit decrease in education will cause 1.09 increases in poverty level among the rice processors. The implication of this is that, since majority of the rice processor have no formal education may contribute hugely on the high rate of poverty among them because they cannot understand the modern means of farming. The poverty rate could increase by 4.8 due to the irregularity of rice processors' income has indicated above, this implies that majority of the rice processors have no other means of income and all their income from rice processing spent without remaining for saving. Also, there was positive coefficient (1.1306) for rice processor gender (female) which reveals enormous significant implication on the rate of poverty level of the rice processors.

Table 4. Logit Regression Estimate of the determinant of poverty among Rice Processors

\begin{tabular}{llll}
\hline Variables & Coefficient & Standard Error & z-value \\
\hline Age & 0.0086 & 0.3043 & 0.28 \\
Gender (female) & $1.306^{* *}$ & 0.6823 & 1.66 \\
Marital status & -0.7041 & 0.8677 & -0.81 \\
Educational status & $-1.0900^{* *}$ & 0.6286 & -1.73 \\
Income & $-4.7885^{* * *}$ & 1.0391 & -4.61 \\
Household size & $-0.0832^{*}$ & 0.9560 & -0.87 \\
Access to credit & 1.0255 & 0.8958 & 1.14 \\
Secondary occupation & 0.6309 & 0.6544 & 0.96 \\
Process per cycle & -1.0719 & 1.1778 & -0.91 \\
Constant & 53.3695 & 12.0519 & 4.43 \\
\hline
\end{tabular}

R square $=0.6876$

Source: Data analysis, 2016

Note $*$ Significant at $10 \%$

** Significant at 5\%

*** Significant at $1 \%$ 
SALAMI M. F., et al.

\section{CONCLUSION AND}

\section{RECOMMENDATIONS}

In conclusion, the study has identified large household size, no formal education, low income and more expenses than income as the major determinants of poverty among the rice processors in the study area. It is therefore recommended that government and other stakeholders should invest more in the education of the rice processors. The rice processors should as well be encouraged to diversify so as to earn more income.

\section{REFERENCES}

1. Foster, J. E.; J. Greer and Thorbecke E., The Foster-Greer-Thorbecke (FGT) Poverty Measures. Twenty-Five Years Later. HEPWP-2010-14. Institute for International Economic Policy. www.gwu.edu/-ilep, 2010.

2. Nsikak-Abasi A. E. and Solomon. V. A., Determinants of Rural Poverty among Broiler Farmers in Uyo, Nigeria: Implication for Rural Household Food Security. Journal of Agricultural and Social Science. Vol. 6. pp. 24 - 28. DOI: 09009/ZIP/2010/6-2-24-28. E-ISSN: 1814960x, P-ISSN: 18132235.www.fspublisher.org, 2010.

3. World Bank Updates, Poverty Estimates for Developing World. World Bank (IBR\&D) Geneva,

Switzerland.www.econ.worldbank.org, 2010.

4. Gustavo A. and Kostas S., Rural Development and Poverty Reduction; Is Agriculture Still the Key?, Working Papers 07-02, Agricultural and Development Economics Division of the Food and Agriculture Organization of the United Nations (FAO - ESA), 2007.

5. Olorunsanya, E. O. and Omotesho. O. A., A
Gender Analysis of Poverty Among Rural Farm Households in North Central, Nigeria. Journal of Social Science. Vol.28. (3). pp. 366 - 376. www.european.com, 2012.

6. Patel, K., Rural Poverty and Nutrition in South Africa. Occasional Paper for International Association of Agriculture Economists (IAAE), 41 Aldershot, U.K. Gower. pp. $79-82,2004$.

7. Agbo, F.U., Cooperative as a Vehicle for Agricultural Adaptation to Climate Change: In Baiyeri P.K. and A.A. Enete (eds). Reading in climate change and Agricultural Adaptation, Publication of the Faculty of Agriculture, University of Nigeria, Nsukka, 2011.

8. Daramola, A.G., Competitiveness of Nigeria Agriculture in a Global Economy: Any Dividends of Democracy? Inaugural Lecture, Series 36, Federal University of Technology, Akure, pp 36. International Bank for Reconstruction and Development, 2004.

9. Olorunsanya, E.O., Babatunde R.O., O.A. Omotesho and G.M. Owotoki, Determinants of Vulnerability to Food Insecurity A Gender-based Analysis of Farming Households in Nigeria Indian Journal of Agricultural Economics Vol. 63 (1): pp116-125, 2008.

10.Omofonmwan, S.I. and M. A. Kadiri., Problems and Prospects of Rice Production in Central District of Edo State, Nigeriace, Journal of Human Ecology 22(2): PpVol. 123-128, 2007.

11.Lwechungura Kamuzora C. and Wiliam Mkanta, Poverty and Household? Family Size in Tanzania: Multiple Responses to Population Pressure? Research on Poverty Alleviation, REPOA report No. 004, 2000. 